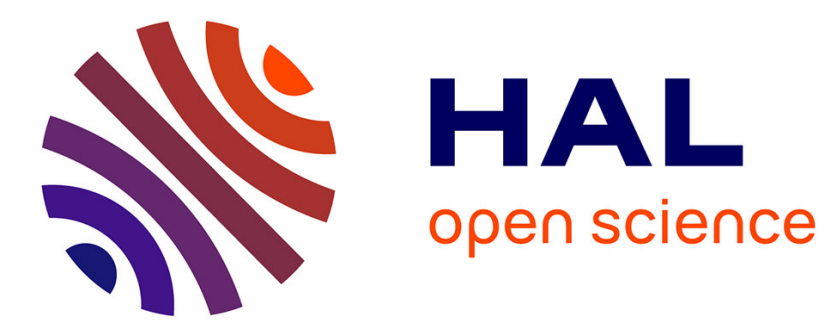

\title{
Climate change risks to civil infrastructure
}

\author{
Emilio Bastidas-Arteaga
}

\section{To cite this version:}

Emilio Bastidas-Arteaga. Climate change risks to civil infrastructure. United Kingdom. Civil Engineering and Environmental Systems, 31 (2), pp.97 - 97, 2014, Civil Engineering and Environmental Systems, 10.1080/10286608.2014.912644 . hal-01081645

\section{HAL Id: hal-01081645 https://hal.science/hal-01081645}

Submitted on 10 Nov 2014

HAL is a multi-disciplinary open access archive for the deposit and dissemination of scientific research documents, whether they are published or not. The documents may come from teaching and research institutions in France or abroad, or from public or private research centers.
L'archive ouverte pluridisciplinaire HAL, est destinée au dépôt et à la diffusion de documents scientifiques de niveau recherche, publiés ou non, émanant des établissements d'enseignement et de recherche français ou étrangers, des laboratoires publics ou privés. 


\section{Climate change risks to civil infrastructure}

This special issue contains a collection of papers of a mini-symposium organized within the framework of the $11^{\text {th }}$ International Conference on Structural Safety andReliability that was held in June 16-20, 2013 at Columbia University, New York, NY. The minisymposium was organized in collaboration with Kazuyoshi Nishijima (Kyoto University, Japan) and Mark Stewart (The University of Newcastle, Australia). The seven papers presented in this special issue were selected from among 17 technical papers originally submitted to the mini-symposium.

Climate projections announce significant future climate changes. Since civil infrastructure has been designed against past climate conditions, climate changecould alsoaffect its serviceability and safety. Therefore, a comprehensive management of climate change risks should consider these new/extreme environmental conditions in order to reduce potential loss of life and assets.

This special issuepresentsdifferent types of hazards/actions (floods, sea level rise, extreme wind events, and physical and chemical actions affecting structural durability)for various types of infrastructure (housing, dams, reinforced concrete structures, and energy and water supply networks). Taking into account that climate change consequences depend on design standards and exposure conditions of given locations, this special issue also includes applications to infrastructure located in several countries: Australia, France, Germany, Japan, South Africa and United Kingdom. These applications and studies cover the following topics:

- risk assessment of climate change effects on civil infrastructure,

- cost-effectiveness and economic viability of climate adaptation technology and engineering measures,

- simplified climate models for engineering purposes, and

- discussions on the needs for updating engineering standards and processes.

It is hoped that this special issuehighlights some of the aspects to be considered on the development of a comprehensive framework of ${ }^{6}$ Climate Adaptation Engineering'to handle climate charge risks in civil engineering. Climate Adaptation Engineering aims atidentifying efficient and cost-effective engineering solutions for climate adaptation. This objectivecan be achieved by integrating climate change science and engineering and itshould provide recommended changes in current engineering practices (design, construction,maintenance, retrofit, etc.) for climate adaptation.

Emilio Bastidas-Arteaga Institute for Research in Civil and Mechanical Engineering, UMRCNRS 6183, Université de Nantes, 2, rue de la Houssinière BP 99208, 44322 Nantes Cedex 3, France emilio.bastidas@univ-nantes.fr 